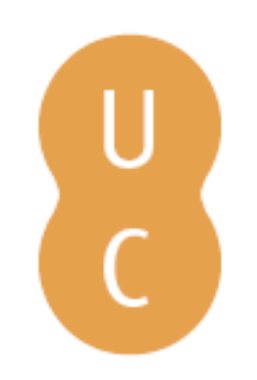

\title{
pommalina
}

\section{An integrated approach to fire emission forecasting}

$\begin{array}{ll}\text { Autor(es): } \quad \text { Kochanski, Adam; Beezley, Jonathan; Jenkins, Mary Ann; Vejmelka, } & \text { Martin; Mandel, Jan }\end{array}$

Publicado por: Imprensa da Universidade de Coimbra

URL

persistente: URI:http://hdl.handle.net/10316.2/34216

DOI: $\quad$ DOI:http://dx.doi.org/10.14195/978-989-26-0884-6_71

Accessed : $\quad$ 26-Apr-2023 15:11:24

A navegação consulta e descarregamento dos títulos inseridos nas Bibliotecas Digitais UC Digitalis, UC Pombalina e UC Impactum, pressupõem a aceitação plena e sem reservas dos Termos e Condições de Uso destas Bibliotecas Digitais, disponíveis em https://digitalis.uc.pt/pt-pt/termos.

Conforme exposto nos referidos Termos e Condições de Uso, o descarregamento de títulos de acesso restrito requer uma licença válida de autorização devendo o utilizador aceder ao(s) documento(s) a partir de um endereço de IP da instituição detentora da supramencionada licença.

Ao utilizador é apenas permitido o descarregamento para uso pessoal, pelo que o emprego do(s) título(s) descarregado(s) para outro fim, designadamente comercial, carece de autorização do respetivo autor ou editor da obra.

Na medida em que todas as obras da UC Digitalis se encontram protegidas pelo Código do Direito de Autor e Direitos Conexos e demais legislação aplicável, toda a cópia, parcial ou total, deste documento, nos casos em que é legalmente admitida, deverá conter ou fazer-se acompanhar por este aviso.

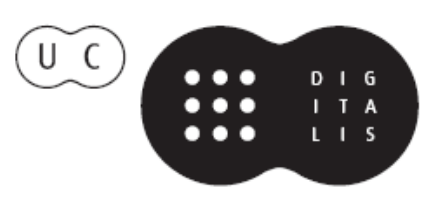




\section{ADVANCES IN}

Forest Fire

\section{RESEARCH}

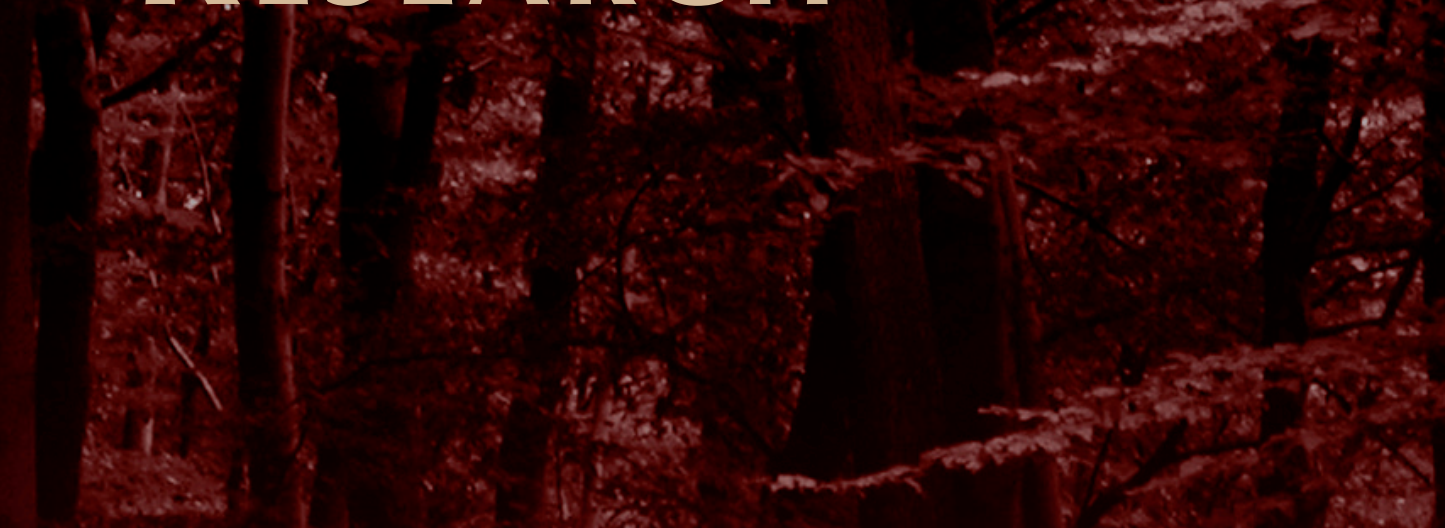

\section{DOMINGOS XAVIER VIEGAS}

\section{EDITOR}




\title{
An integrated approach to fire emission forecasting
}

\author{
Adam Kochanski ${ }^{\mathrm{a}}$, Jonathan Beezley ${ }^{\mathrm{b}}$, Mary Ann Jenkins ${ }^{\mathrm{c}}$, Martin Vejmelka ${ }^{\mathrm{d}}$, Jan Mandel ${ }^{\mathrm{e}}$ \\ ${ }^{a}$ Atmospheric Sciences Department, University of Utah, Salt Lake City, Utah, USA \\ adam.kochanski@utah.edu \\ ${ }^{b}$ Kitware, Inc., Clifton Park, New York, USA \\ jon.beezley@gmail.com \\ ${ }^{c}$ Department of Earth and Space Science and Engineering, York University, Toronto, Canada \\ maj@yorku.ca \\ ${ }^{d}$ Department of Mathematical and Statistical Sciences, University of Colorado, Denver, USA \\ Martin.Vejmelka@ucdenver.edu \\ ${ }^{e}$ Department of Mathematical and Statistical Sciences, University of Colorado, Denver, USA \\ jan.mandel@ucdenver.edu
}

\begin{abstract}
In this study, we describe how WRF-SFIRE is coupled with WRF-Chem to construct an integrated forecast system for wildfire and smoke prediction. The integrated forecast system has the advantage of not requiring a separate plume-rise model and assumptions about the size and heat release from the fire in order to determine fire emissions into the atmosphere. With WRF-SFIRE, wildfire spread, plume and plume-top heights are predicted directly, at every WRF time-step, providing comprehensive meteorology and fire emissions to the chemical transport model WRF-Chem. Evaluation of the system was based on comparisons between available observations to the simulations of the 2007 Santa Ana fires. The study found overall good agreement between forecasted and observed fire spread and smoke transport for the Witch-Guejito fire. Also the simulated PM2.5 (fine particulate matter) peak concentrations matched the observations. However, the NO and ozone levels were underestimated in the simulations and the peak concentrations were mistimed. Determining the terminal or plume-top height is one of the most important aspects of simulating wildfire plume transport, and the study found overall good agreement between simulated and observed plume-top heights.
\end{abstract}

Keywords: fire modeling, smoldering, smouldering, smoke, air quality, emissions, dispersion, plume rise

\section{Introduction}

A wide suite of tools exists that can be used to help assess smoke dispersion. They range from simple Gaussian smoke models that aim to assess the area affected by smoke based on fuel type, fire area and wind conditions, to complex multi-model systems predicting the emissions, dispersion and air quality effects associated with wildland fires. The latter ones generally use a set of specialized sub-models, designed to perform specific tasks associated with the fire emission forecasting. The multi-model systems typically consist of a fuel consumption model, providing an estimate of the amount of burnt fuel, an emission model, computing fluxes of chemical species, a plume rise model, assessing the injection height, and a chemical and transport model, computing how the species react and disperse in the atmosphere. The fire emissions and plume dispersion may be linked to meteorological conditions, by feeding these models with weather data provided by a separate numerical weather prediction model. There are two major limitations of this approach. First, this modular approach generally does not capture the two-way interactions between the system components. For instance, even if fire spread and fuel consumption are computed based on the simulated weather forecast, the fire's convection is not coupled to, and represented in, the weather model. The weather prediction used for fire progression will not therefore include local, fire-affected weather conditions. As a consequence, the inaccuracies in the prediction of the local weather conditions may adversely affect estimates of the plume height and dispersion, both which depend heavily on the weather input. 
The second drawback is the limited fidelity of such a system in terms of realistic representation of the fire progression, fire emissions, plume rise, and plume dispersion. For example, a typical plume-rise model is based on classical plume theory, and assumes a single idealized Gaussian-shaped plume (in most cases, rising vertically; i.e., not bent-over) placed over a point-source fire. In reality, both the surface fire emissions and fire plume behaviour are much more complex. The majority of the flaming emissions take place at the fire perimeter, while the smoldering may be a source of emissions within it. Regions of high fire activity can induce more than one strong updraft core, ingesting fire emissions at much higher rates than is estimated by the typical plume rise model, while strong winds may limit the plume rise to much lower elevations than those predicted by an idealized plume rise model.

In this paper we present a new integrated approach to the problem of the simulation of the fire emissions. We show an integrated modelling framework that predicts fire progression, taking into account the fire-weather and fuel-weather feedbacks, and explicitly resolves fire-induced convective plumes, as well as simulates the chemical reactions, transport, and dispersion of the fire-emitted species in the atmosphere.

\section{Model description}

The core of the system is the WRF-SFIRE model (Mandel et al., 2011), which is a two-way coupled fire atmosphere model based on Weather Research and Forecasting model (WRF - Skamarock et al., 2005) and Rothermel (1972) fire spread model implemented by a level set method. WRF-SFIRE has evolved from the CAWFE code (Clark et al., 1996, 2004), which was built on the Clark-Hall code. The switch to WRF allowed faster than real time parallel execution on fine meshes and a natural coupling with WRF-Chem. WRF-SFIRE predicts fire spread based on local meteorological conditions, taking into account the feedback between the fire and atmosphere.

To capture the effects of local weather on fuel characteristics, WRF-SFIRE is also coupled with a fuel moisture model, which assesses the fuel moisture based on local meteorology (air humidity, temperature, and precipitation). The fire-emitted heat (computed by the fire model) is fed into the atmospheric component of the model, so WRF-SFIRE dynamically simulates and resolves the fire convection and plume rise. The mass of the burnt fuel in the WRF-SFIRE simulation is used to estimate the fire emissions associated with flaming and smoldering in every time step. The linked WRF-Chem (Grell et al., 2005) predicts the transport, dispersion, and chemical conversion in the atmosphere of the fire-emitted chemical species as the plume evolves. The impact of fire emitted heat on the plume characteristics accounts for different plume injection heights. Emissions from regions of high intensity fires are carried higher by stronger updrafts and greater plume rise, than from lower intensity fires generating weaker updrafts. 

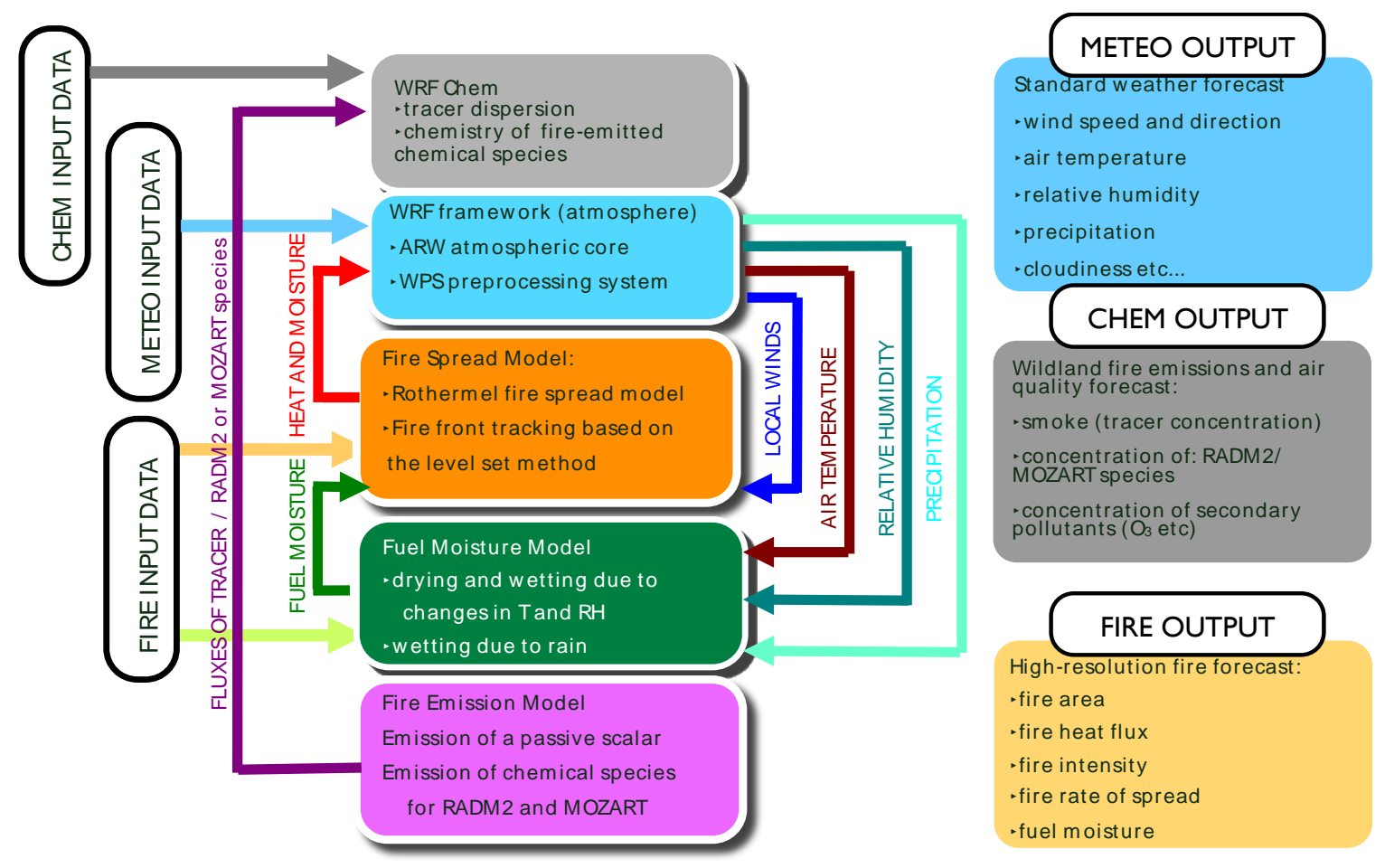

Figure 1. Diagram of the integrated fire emission system based on WRF-SFIRE coupled with moisture model and WRF-Chem

In this model framework, the model resolves the fire plumes instead of parameterizing them, and instantaneous fire activity at any given place is linked with the fire-driven emissions, fluxes, buoyancy, and local winds. Assumptions about the vertical distribution of the fire emission as part of a sub-grid scale parameterization based on classical plume theory are therefore avoided, as the vertical dispersion of the fire emissions are simulated by the model explicitly. The diagram showing the WRF-SFIRE model components is presented in Figure 1.

The fire emissions are estimated based on the combustion rates computed for each fire-grid point as the mass of fuel consumed within one WRF time step. Once the fuel consumption is known, emission fluxes are computed as the products of the fuel-combustion rates and the fuel-specific emission factors. Currently the global fire emission factors from FINN (Fire INventory from NCAR, Wiedinmeyer $e t$ al., 2011) are used, however; the model also accepts user-defined emission factors provided in one of the model configuration files. The fire emissions are represented as a sum of the fluxes of the chemical species compatible with two chemical mechanisms supported by WRF-Chem - MOZART (Emmons et al. 2010), and RADM2 (Stockwell et al. 1990) as presented in Figure 2. The emission fluxes are then ingested into the first model layer of WRF-Chem, which handles dispersion and chemical transformation of the fire emissions. 


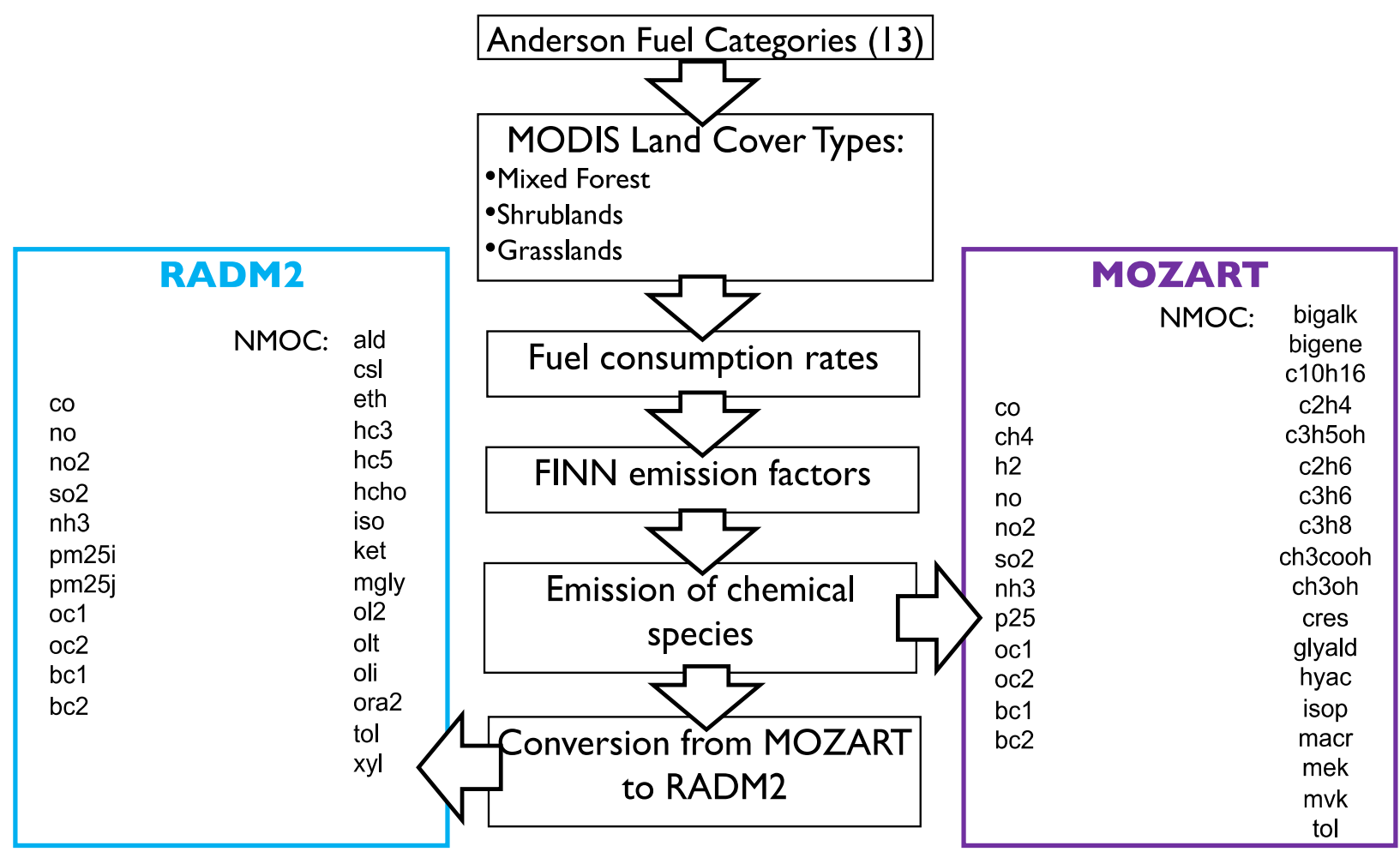

Figure 2. Computation of fire emissions in the WRF-based integrated system for fire and air quality simulations.

\section{Model setup}

We tested the system on the 2007 Witch and Guejito Santa Ana fires. In order to model evolution of the Santa Ana event, together with the local circulation dictated by the complex topography of southern California, WRF was configured with four nested domains: D01, D02, D03, and D04, of horizontal-grid sizes $32 \mathrm{~km}, 8 \mathrm{~km}, 2 \mathrm{~km}$, and $500 \mathrm{~m}$, respectively, as shown in Figure 3. The model's vertically-stretch grid extended up to $15.4 \mathrm{~km}$, with a surface layer roughly $20 \mathrm{~m}$ thick and the topmost vertical layer roughly $2000 \mathrm{~m}$ thick. The surface fire mesh located in domain D04 had a refinement ratio of 25 , making the horizontal fire-grid cell size $20 \mathrm{~m}$. Output from the fire simulation was saved every 10 minutes. The fire model, SFIRE, used 30m-resolution elevation and fuel data, while the atmospheric model, WRF, used approximately $1.5 \mathrm{~km}$-resolution MODIS land-use representation. Further details of this setup can be found in Kochanski et al. (2013). 


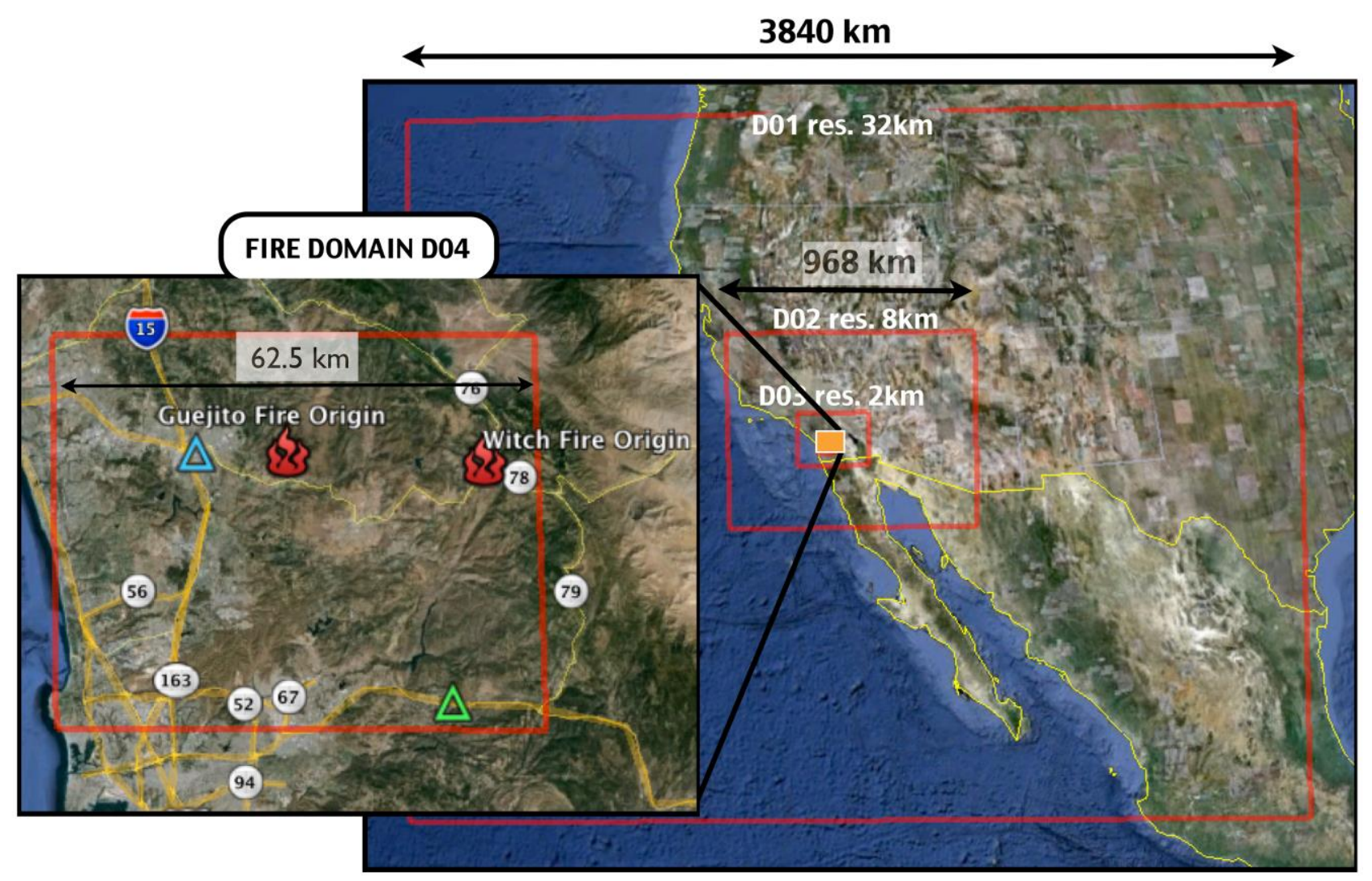

Figure 3. The multi-scale WRF setup in this study, including locations of the Witch and Guejito fire origins and the air quality stations used for model validation (Escondido - blue triangle; Alpine - green triangle). Horizontal domain resolutions vary from $32 \mathrm{~km}$ (D01) to $500 \mathrm{~m}$ (D04).

\section{Results and discussion}

The model's ability to accurately resolve the plume height was evaluated using available satellite data. There was no MISR (Multi-angle Imaging SpectroRadiometer) data collected for this particular fire, but there were two other nearby fires actively burning at approximately the same time (see Table 1).

Table 1. MISR plume retrieval data for wildfires in the vicinity of Witch-Guejito fire on date 200710-21 and time 18:39:52 UTC. SDev = Standard Derivation

\begin{tabular}{|c|c|c|c|c|c|c|}
\hline Longitude & Latitude & $\begin{array}{c}\text { Plume } \\
\text { Perimeter } \\
\text { Length }\end{array}$ & $\begin{array}{c}\text { Plume } \\
\text { Area } \\
{\left[\mathrm{km}^{2}\right]}\end{array}$ & $\begin{array}{c}\text { Median } \\
\text { Plume } \\
\text { Height } \\
{[\mathrm{m} \mathrm{AGL}]}\end{array}$ & $\begin{array}{c}\text { Top } \\
\text { Plume } \\
\text { Height } \\
{[\mathrm{m} \text { AGL] }}\end{array}$ & SDev \\
\hline-117.441 & 33.244 & 70 & 259 & 943 & 1260 & 269 \\
-116.562 & 32.623 & 269 & 2168 & 684 & 1017 & 314 \\
\hline
\end{tabular}

The maximum simulated plume top height for the Witch and Guejito fires computed from the PM2.5 field using $1 \mu \mathrm{g} / \mathrm{m}^{3}$ threshold was $1574 \mathrm{~m}$. This is slightly higher than suggested by the MISR data for the two nearby fires, but it has to be noted that they were also smaller than the Witch and Guejito fires. The two-way coupling between the WRF domains enables pollution transport across the domains, so the smoke emitted from the fire simulated within the inner most domain is also present in the outer domain D03, which may resolve larger-scale smoke transport. An example of the smoke dispersion simulated in the D03 and the visible satellite picture are presented Figure 4. 

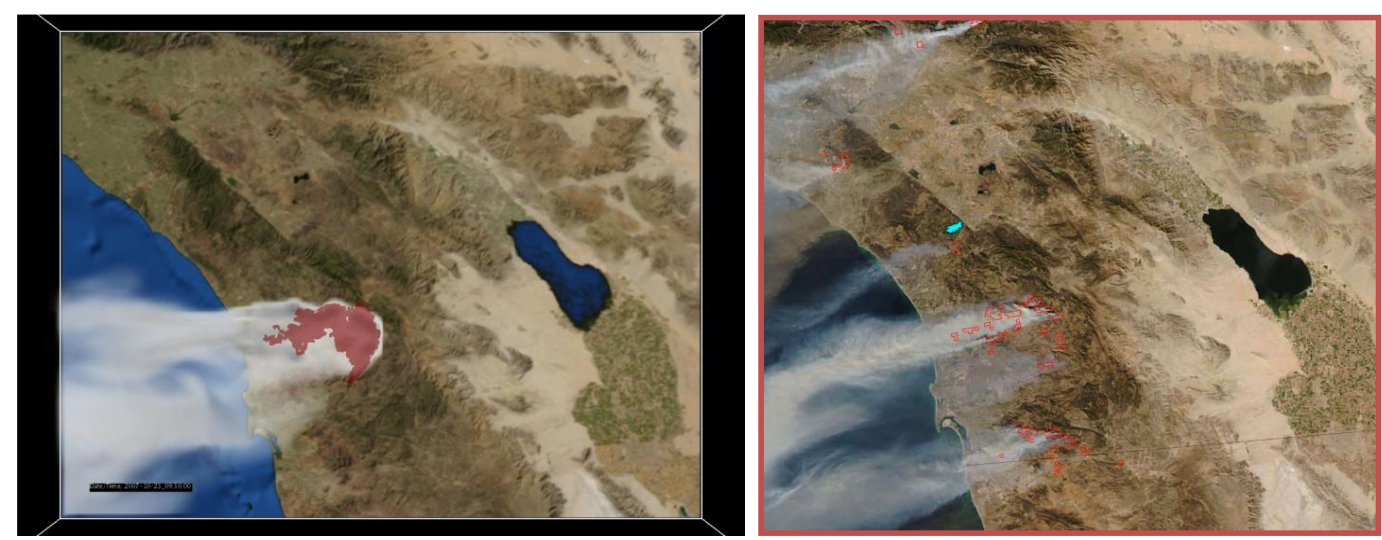

Figure 4. Smoke dispersion within domain D03 (2km resolution) simulated by WRFSC (left panel) and MODIS satellite image (right panel). The red color fill in left panel represents the fire area projected from the nested fire domain D04 (500m resolution). Red contours in right panel represent remotely detected hot spots.

The transport and dispersion of the fire-emitted pollutants as well as the chemical processes simulated by the model were tested based on the surface measurements of the PM25 and NO. An example of the time series of the PM2.5 and NO concentrations simulated by the model and observed by Escondido air quality station (green triangle in Figure 3) are presented in Figures 5 and 6.

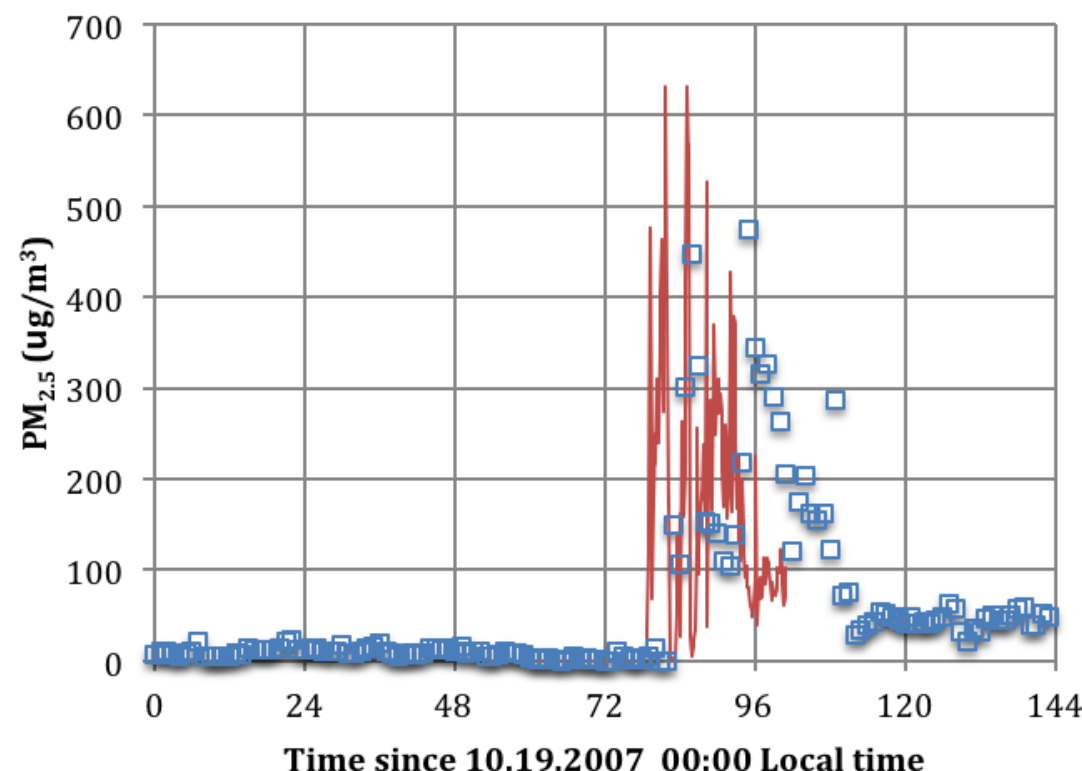

$\square$ Observations

WRF-SFIRE

Figure 5. Time series of the simulated (red line) and observed (blue squares) PM25 concentrations at Escondido air quality station. 


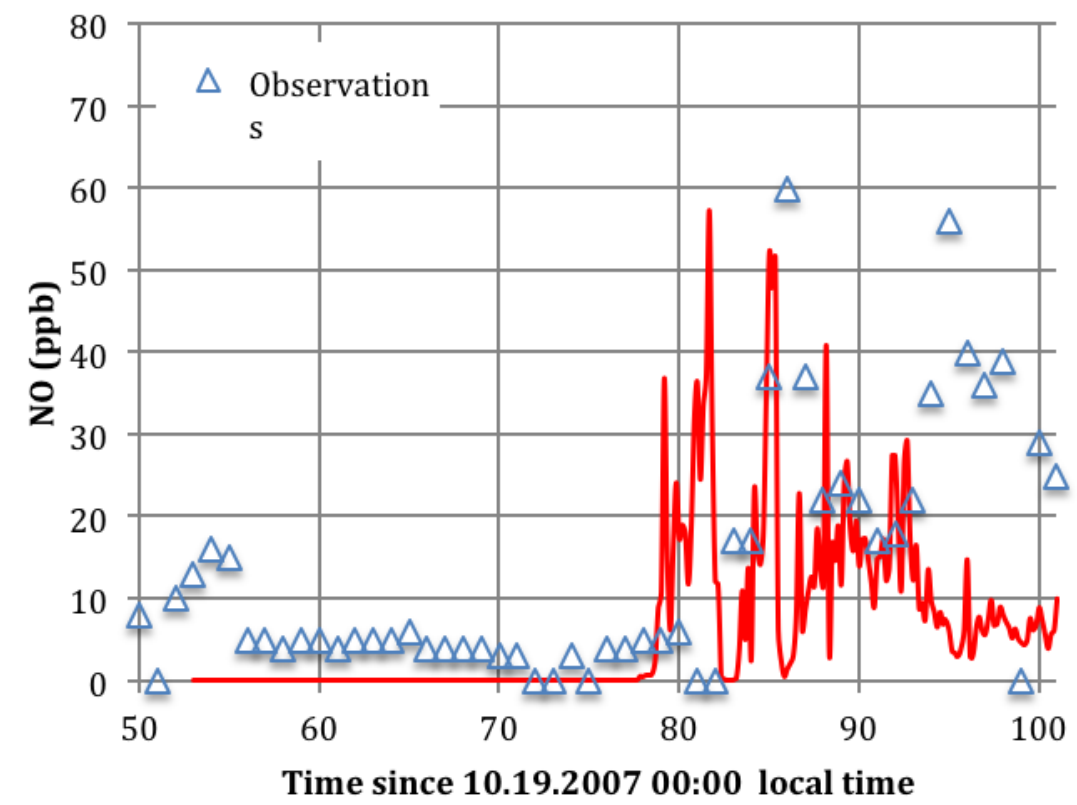

Figure 6. Time series of simulated (red line) and observed (blue triangles) NO concentration at Escondido air quality station.

In terms of the PM2.5 the modelled instantaneous values were slightly higher than the observed ones. The model estimated peaks at $632 \mu \mathrm{g} / \mathrm{m}^{3}$ while the observations show maximum hourly values at 475 $\mu \mathrm{g} / \mathrm{m}^{3}$. It has to be noted that the WRF-predicted values peaked a couple of hours earlier than observed ones. The time shift between observed and simulated peaks can possibly be attributed to an overestimation in the north-west fire progression toward Escondido. Kochanski et al. (2013a) determined that the simulated fire progressed approximately $10 \mathrm{~km}$ further in the north-west direction than the actual fire.

In terms of the NO concentrations, the model slightly underestimated the concentration, predicting peak values of $57.3 \mathrm{ppb}$, while the observed NO peaked at $60 \mathrm{ppb}$. Similarly like in the case of PM2.5, the timing of the simulated NO peaks appear earlier than in observations.

In a complex modelling system like WRF-SFIRE coupled with WRF-Chem, it is very difficult to determine directly reasons for the discrepancies between the simulated and observed pollutants levels. One reason may be that the three MODIS Land Cover Types used for emission computations (i.e., mixed forest, shrublands, and grasslands) are not detailed enough to represent the chemical smoke composition from fires spreading across 13 different fuel-bed categories (Anderson 1982). Another reason may be that global NO emission factors for grass and shrubs may be slightly lower than the actual NO emission factors for the fuel types in the Witch-Guejito region of Southern California. Finally the simulated local meteorology and smoke dispersion, as well as the fire progression are not perfect. Nonetheless, these differences between PM2.5 and NO simulated and observed are relatively low, and show promise for integrated fire-emissions forecasts.

\section{Summary}

In this paper, we presented an integrated system for simulating fire progression and fire impacts on air quality. The system utilizes the WRF-SFIRE as a component resolving the fire spread forecast and plume rise, and the WRF-Chem handling the chemical transport of fire-emitted pollutants. This pilot study is designed to demonstrate the potential of WRF-Sire and WRF-Chem as an integrated system for use by researchers and resource managers. What the study does establish is the increased level of detail provided by the system, such as locations of high reaction intensity, smoke emissions, and plume 
injection heights that can provide a more comprehensive understanding of the wildfire environment, wildfire behaviour, and downwind ramifications of wildland fire emissions on air quality. Future quantitative research is warranted to prove the validity WRFSC, and evaluation of the model by comparison to new and different data sets is necessary. Observations that provide information for all components of the system - local micrometeorology, fire spread, fire emissions, plume rise, and dispersion and chemistry - are needed. Coordinated field measurements of fire spread data, fire heat release, and in-situ meteorological conditions are required to evaluate the fire spread component of the system. Radiosonde data are needed to provide information on the vertical structure of wind, moisture and temperature. Airborne measurements in the smoke plume of the updraft velocities, temperature, and chemical composition, combined with estimates of local emission factors, are needed to analyse fire-plume dynamics, dispersion, and chemistry. A comprehensive dataset providing information on all these aspects is essential to fully understand how the integrated system performs and what components need to be improved.

\section{Acknowledgements}

This research was partially supported by the National Science Foundation (NSF) grant DMS-1216481, and National Aeronautics and Space Administration (NASA) grants NNX12AQ85G and NNX13AH9G. This work partially utilized the Janus supercomputer, supported by the NSF grant CNS-0821794, the University of Colorado Boulder, the University of Colorado Denver, and the National Center for Atmospheric Research.

\section{References}

Anderson H (1982) Aids to determining fuel models for estimating fire behavior. Technical Report INT-122, USDA Forest Service, Intermountain Forest and Range Experiment Station, Ogden, UT, USA, 22 pp.

Clark TL, Jenkins MA, Coen J, Packham D (1996) A coupled atmospheric-fire model: Convective feedback on fire line dynamics. J. Appl. Meteor, 35, 875-901, doi:10.1175/15200450(1996)035<0875:ACAMCF>2.0.CO;2.

Clark TL, Coen J, Latham D (2004) Description of a coupled atmosphere-fire model. International Journal of Wildland Fire, 13, 49-64, doi:10.1071/WF03043.

Emmons L, Walters S, Hess P, Lamarque J, Pfister G, Fillmore D, Granier C, Guenther A, Kinnison D, Laepple T, Orlando J, Tie X, Tyndall G, Wiedinmeyer C, Baughcum S, Kloster S (2010) Description and evaluation of the model for ozone and related chemical tracers, version 4 (MOZART-4). Geoscientific Model Development 3, 43-67, doi:10.5194/gmd-3-43-2010.

Grell G, Peckham S, Schmitz R, McKeen S, Frost G, Skamarock W, and Eder B (2005) Fully

coupled "online" chemistry within the WRF model. Atmospheric Environment 39, 6957-6975, doi:10.1016/j.atmosenv.2005.04.027.

Kochanski AK., Jenkins MA, Krueger S, Mandel J, Beezley JD (2013a) Real time simulation of 2007 Santa Ana fires. Forest Ecology and Management, 15, 136-149, doi:10.1016/j.foreco.2012.12.04

Kochanski A., Jenkins, MA, Mandel J, Beezley JD, Clements CB, Krueger S (2013b): Evaluation of WRF-SFIRE performance with field observations from the FireFlux experiment. Geoscientific Model Development, 6, 1109-1126, doi:10.5194/gmd-6-1109-2013

Mandel J, Beezley JD, Kochanski AK (2011) Coupled atmosphere-wildland fire modeling with WRF 3.3 and SFIRE 2011. Geoscientific Model Development, 4, 591-610, doi:10.5194/gmd-4-12011.

Rothermel R (1972) A mathematical model for predicting ire spread in wildland fuels. Technical Report Research Paper INT 115. (Ogden, UT), USDA Forest Service, Intermountain Forest and 
Range Experiment Station, 46pp.

Stockwell WR, Middleton P, Chang JS, Tang X (1990) The second generation regional acid deposition model chemical mechanism for regional air quality modeling, J. Geophys. Res., 95(D10), 1634316367, doi:10.1029/JD095iD10p16343.

Wiedinmeyer C, Akagi S, Yokelson R, Emmons L, Al-Saadi J, Orlando J, Soja A (2011)

The Fire INventory from NCAR (FINN): a high resolution global model to estimate the emissions from open burning. Geoscientific Model Development 4, 625-641, doi:10.5194/gmd-4-625-2011. 